\title{
Kualitas Pelayanan Publik Dalam Penyediaan Air Bersih Di Desa Bulontio Barat Kecamatan Sumalata Kabupaten Gorontalo Utara
}

\author{
${ }^{1}$ Apris A Tilome, ${ }^{2}$ Rusli Abd Idji, ${ }^{3}$ Rita Lakoro \\ ${ }^{I}$ Program Studi Administrasi Negara Fakultas Ekonomi dan Ilmu Sosial \\ ${ }^{2,3}$ Program Studi Administrasi Negara Fakultas Ekonomi dan Ilmu Sosial \\ Universitas Muhammadiyah Gorontalo, Gorontalo,Indonesia \\ Email :apristilome@yahoo.com
}

\begin{abstract}
This research was conducted in the village of West Bulontio Sumalata District of North Gorontalo District. The purpose of this study was to determine the quality of service in the supply of water by taps in the village Bulontio Sumalata Western District of North Gorontalo District. A study that describes the water supply from the taps that are still not able to meet the needs of citizens, service by officials still have not been up in response to the desire of citizens, poor human resource quality is not adequate. The research result that the quality of public services addressing water supply in the village of West Bulontio Sumalata District of Gorontalo district can be quite good though not optimal and should be improved in both technical and non-technical.
\end{abstract}

Keywords: Quality;; Public; Services; Water

\begin{abstract}
Abstrak
Penelitian ini dilaksanakan di Desa Bulontio Barat Kecamatan Sumalata Kabupaten Gorontalo Utara. Tujuan dari penelitian ini adalah untuk mengetahui kualitas pelayanan dalam penyediaan air bersih oleh BLU-SPAM di Desa Bulontio Barat Kecamatan Sumalata Kabupaten Gorontalo Utara. Suatu penelitian yang menggambarkan Pasokan air dari BLU-SPAM yang masih belum mampu memenuhi kebutuhan warga, Pelayanan oleh aparat yang sudah maksimal dalam merespon keinginan warga, Kualitas sumber daya aparat yang belum memadai. Hasil penelitian menujukan bahwa kualitas pelayanan publik penyediaan air bersih di Desa Bulontio Barat Kecamatan Sumalata Kabupaten Gorontalo dapat dikatakan cukup baik meskipun belum optimal dan harus lebih ditingkatkan lagi baik secara teknis maupun non teknis.
\end{abstract}

Kata Kunci: Kualitas; Publik; Pelayanan; Air 


\section{PENDAHULUAN}

Pemenuhan kebutuhan air minum rumah tangga baik masyarakat di desa maupun di perkotaan merupakan salah satu pelayanan dasar primer yang sangat dibutuhkan. Pelayanan pemenuhan air menjadi sangat penting dikarenakan semakin meningkatnya permintaan air itu sendiri seiring dengan pertambahan populasi penduduk. Beberapa masalah yang muncul kemudian adalah masih terbatasnya sumber daya manusia, baik yang ada di pemerintah kecamatan maupun pemerintah kabupaten dalam memberikan pelayanan yang maksimal kepada masyarakat khususnya dalam pengelolaan air bersih dan layak konsumsi oleh Badan Layanan Umum-Sarana Penyediaan Air Minum (BLU-SPAM). Ketersediaan sarana dan fasilitas pendukung juga masih menjadi hal klasik dalam meningkatkan kualitas pelayanan penyediaan air, padahal dalam regulasinya, keberadaan BLUSPAM bertujuan untuk terciptanya pengelolaan dan pelayanan air minum yang berkualitas dan berkontinuitas kepada publik dengan harga yang terjangkau.

Kinerja BLU-SPAM yang baik akan memberi konstribusi terhadap pencapaian tujuan organisasi maupun pelayanan publik yang diberikan. BLU-SPAM merupakan Badan usaha milik daerah yang masuk dalam kategori penyelenggara pelayanan yang bersifat profit dengan tugasnya memberikan pelayanan air bersih kepada warga masyarakat pada suatu daerah. BLU-SPAM adalah unit yang memberikan pelayanan yang terbaik kepada masyarakat satu instansi pemerintah yang berbentuk BUMD memiliki jenis pelayanan yang termasuk dalam kelompok pelayanan barang yaitu pelayanan yang menghasilkan berbagai bentuk/jenis barang dalam hal ini adalah penyediaan air bersih.
Salah satu wilayah yang ada di Kabupaten Gorontalo Utara yakni di Kecamatan Sumalata sudah menikmati pelayanan air bersih, namun dari pengamatan penulis sampai saat ini pelayanan tersebut masih belum dapat dinikmati oleh sebagian masyarakat secara maksimal, di Kecamatan Sumalata.

Beberapa hal yang menjadi indikasi dan faktor penyebab tidak maksimalnya kualitas pelayanan tersebut antara lain disebabkan oleh adanya air yang masih sering macet dalam hal ini tidak berjalan lancar, pasokan air yang tidak mampu memenuhi jumlah pelanggan yang menyebabkan kinerja pegawai BLUSPAM yang dianggap kurang mementingkan kepentingan pelanggan. Di samping itu keterbatasan jumlah pegawai BLU-SPAM belum memadai yang seharusya berjumlah 11 orang, disediakan hanya 9 orang, yang menyebabkan penumpukan kerja yang tidak sesuai dengan kondisi di lapangan, yang menyebabkan kualitas pelayanan terhadap penyediaan air bersih di Kecamatan Sumalata kuarang optimal. Menurut J.Supranto (2006:226) adalah sebuah kata yang bagi penyedia jasa merupakan sesuatu yang harus dikerjakan dengan baik. Dalam salah satu studi mengenai kualitas pelayanan oleh Parasuraman (1988) yang melibatkan 800 pelanggan (yang terbagi dalam empat perusahaan) berusia 25 tahun ke atas, disimpulakn bahwa terdapat lima dimensi kualitas pelayanan (Tjiptono, Chandra dan Adriana:2008), sebagai berikut :

\section{Berwujud (tangible)}

Merupakan kemampuan suatu perusahaan dalam menunjukkan eksistensinya kepada pihak eksternal. Penampilan dan kemampuan sarana dan prasarana fisik perusahaan yang dapat 
diandalkan keadaan lingkungan sekitarnya merupakan bukti nyata dari pelayanan yang diberikan oleh para pemberi jasa. Hal ini meliputi fasilitas fisik (contoh : gedung, gudang dan lain-laian), perlengkapan dan peralatan yang digunakan (teknologi) serta penampilan pegawainya).

\section{Keandalan (reliability)}

Adalah kemampuan perusahaan untuk memberikan pelayanan sesuai dengan dijanjikan secara akurat dan terpercaya. Kinerja harus sesuai dengan harapan pelanggan yang berarti ketepatan waktu, pelayanan yang sama untuk semua pelanggan tanpa kesalahan, sikap yang simpatik dan dengan akurasi yang tinggi.

3. Ketanggapan (responsiveness)

Yakni suatu kebijakan untuk membantu dan memberikan pelayanan yang cepat (responsive) dan tepat kepada pelanggan dengan penyampaian informasi yang jelas. Membiarkan konsumen menunggu adalah persepsi yang negative dalam kualitas pelayanan.

4. Jaminan dan kepastian (assurance)

Adalah

pengetahuan, kesopansantunan dan kemampuan para pegawai perusahaan untuk menumbuhkan rasa percaya para pelanggan kepada perusahaan. Hal ini meliputi beberapa komponen anatara lain komunikasi (communication), kredibilitas (credibility), keamanan (security), kompetensi (competence) dan sopan santun (courtesy).

5. Empati (empathy)

Maknanya memberikan perhatian yang tulus dan bersifat individual atau pribadi yang diberikan kepada para pelanggan dengan berupaya memahami keinginan konsumen. Dimana suatu perusahaan diharapkan memilki pengertian dan pengethauan tentang pelanggan, memahami kebuthuhan pelanggan secara spesifik, serta memilki waktu pengoperasian yang nyaman bagi pelanggan. Kualitas pelayanan dibangun atas adanya perbandingan dua faktor utama, yaitu persepsi pelanggan atas layanan yang nyata mereka terima (perceived service) dengan layanan yang sesungguhnya diharapkan (expected service).

Jika kenyataannya lebih dari yang diharapkan maka layanan dapat dikatakan berkualitas, dan sebaliknya. Singkat kata, kualitas pelayanan dapat didefinisikan sebagai seberapa jauh perbedaaan antara kenyataan dan harapan pelayanan pelanggan yang mereka terima (Parasuraman, dkk: 1998).

Dari uraian yang telah dijelaskan sebelumnya mengenai deskripsi pelayanan yang diberikan oleh BLU-SPAM dalam penyediaan air bersih di Kecamatan Sumalata, mencerminkan bahwa kualitas pelayanan yang ada belum maksimal dengan adanya kondisi yang ada di lapangan terkait pelayanan tersebut, olehnya itu untuk mengetahui lebih detail tentang kondisi ini maka kami melakukan penelitian dengan judul "Kualitas Pelayanan Publik Dalam Penyediaan Air Bersih Oleh BLU-SPAM di Kecamatan Sumalata Kabupaten Gorontalo Utara”.

Berdasarkan latar belakang dan identifikasi malasalah tersebut maka masalah dalam penelitian yang akan dilaksanakan ini difokuskan pada: Bagaimana Kualitas Pelayanan Penyediaan Air Bersih oleh BLU-SPAM di Kecamatan Sumalata,Kabupaten Gorontalo Utara. Adapun yang menjadi tujuan penelitian ini adalah untuk mengetahui kualitas pelayanan dalam penyediaan air bersih oleh BLU-SPAM di kecamatan sumalata kabupaten gorontalo utara. 


\section{METODE PENELITIAN}

\section{Pendekatan Dan Jenis Penelitian}

Penelitian ini menggunakan jenis penelitian deskriptif dengan pendekatan kualitatif, penelitian deskriptif didasarkan pada pertimbangan bahwa data akan diperoleh dengan lebih lengkap, mendalam dan terpercaya serta dapat ditemukan kejadian dalam konteks sosial.

Lokasi penelitian ini dilaksanakan di Kecamatan Sumalata Kabupaten Gorontalo Utara dengan pertimbangan lokasi ini mudah dijangkau oleh peneliti, dalam proses pengambilan data, sehingga peneliti melakukan tujuan sesuai dengan yang telah direncanakan.

\section{Prosedur Pengumpulan dan Analisi Data}

Pengumpulan data dilakukan dengan penelitian dilapangan, yaitu peneliti terjun langsung kelokasi penelitian untuk mendapatkan data yang diperlukan. Teknik yang digunakan untuk mengumpulkan data dalam penelitian ini adalah:

1. Observasi, yaitu melakukan pengamatan langsung dengan melakukan pencatan terhadap gejala-gejala yang dijumpai dilapangan. Menurut Creswell (2010;267), observasi merupakan kegiatan peneliti yang langsung turun kelapangan untuk mengamati perilaku dan aktivitas individu-individu di lokasi penelitian.

2. Wawancara, yaitu melakukan tanya jawab langsung dengan pihak yang terkait mengenai permasalahan yang terjadi, guna untuk melengkapi data informasi. Informan yang diwawancarai dalam penelitian ditentukan secara Purposive, dengan melihat kesesuaian antara calon informan dengan informasi yang dibutuhkan. Artinya, informan yang akan dipilih adalah mereka yang betul-betul memiliki pengetahuan tentang pelayanan dalam penyediaan air bersih oleh BLUSPAM Kecamatan Sumalata

3. Dokumentasi, yaitu cara mengumpulkan data yang dapat diperoleh melalui sumbersumber data yang di anggap relevan, baik yang melalui majalah, maupun, makalah, buku-buku, surat-surat, surat kabar berita kualitat maupun sumber informasi lainnya seperti arsip, dalil, hukum-hukum, hasil penelitian dan lain sebagainya.(Suharsimi Arikunto, 2010:234). Adapun teknik analisis data yang digunakan untuk memecahkan permasalahan dalam penelitian ini adalah analisis deskriptif, yaitu proses analisisnya dimulai dengan menelaah dan mengkaji seluruh data yang telah diperoleh dari berbagai sumber yang terkait, dan diuraikan dalam bentukkalimat-kalimat yang logis untuk ditarik kesimpulannya. Teknik analisis selama proses pengumpulan data dilakukan dengan cara induksi yang artinya analisis didasarkan pada keadaan yang nyata dilapangan, dan bukan berdasarkan hanya pemikiran, pemahaman apalagi kepentingan objek peneliti.

\section{HASIL DAN PEMBAHASAN}

Penelitian ini difokuskan pada beberapa indikator dalam mengukur kualitas pelayanan oleh penyedia jasa air minum yakni Perusahaan daerah air minum (BLU-SPAM) dalam memberikan jasanya kepada masyarakat di Desa Bulontio barat, kecamatan Sumalata Kabupaten Gorontalo Utara. Adapun indikator-indikator yang digunakan dalam penelitian ini ialah meliputi : Realibilty, Responsiveness, Emphaty, Assurance dan Tangibles. Adapun pembahasan tiap-tiap indikator adalah sebagai berikut :

\section{Dimensi Kererandalan (Reliability)}


Berdasarkan hasil temuan di lapangan dengan melaksanakan wawancara kepada informan. Wawancara yang dilakukan dengan Kepala BLUSPAM tentang keandalan aparat dalam melancarkan prosedur pelayanan dikatakan bahwa :

"Dalam melancarkan prosedur pelayanan yang berada dikantor yang dipimpinnya langsung memang sudah sesuai dengan prosedur yang ada. Namun untuk menghilangkan berbagai keluhan dari pelanggan memang adalah hal yang tak bisa dihindari karena melihat berbagai hal yang terjadi, sehingga apa yang diinginkan masyarakat belum semuanya dapat teratasi, misalnya kebocoran pipa, pemadaman listrik yang berjam-jam, hal itulah hal yang paling beresiko dalam pelayanan". (WW, FK,02-02-2016)

Selanjutnya Kepala Desa Bulontio Barat dalam wawancaranya mengatakan bahwa:

"Kemampuan dan keandalan aparat didalam pelayanannya terhadap penyediaan air bersih didesa bulontio barat belum maksimal. Penyebabnya adalah kurannya pasokan air bersih dan sulitnya untuk mendapatkan air yang tersedia". (WW,HTM, 02-02-2016)

Selanjutnya hasil wawancara dengan responden yang lain yaitu Kepala Dusun Tengah :

"Selama ini saya sebagai pelanggan merasakan selama bertahun-tahun bahwa kurangnya air yang dibutuhkan sehingga tidak cukup untuk kebutuhan dalam rumah tangga" (WW,L,03-02-2016)

Berdasarkan hasil wawancara tersebut di atas dapatlah disimpilkan bahwa dalam pelayanan di BLU-SPAM desa bulontio barat kecamatan sumalata sudah sangat baik tapi oleh karena kurangnya personil dilapangan hal tersebut sedikit menghambat proses pelayanan terhadap masyarakat.

\section{Dimensi Bukti Fisik (Tangibles)}

Hasil wawancara dengan kepala BLU-SPAM tentang pendapat bapak apakah di kantor BLU-SPAM ada ruang tunggu pelayanan.Kepala BLU-SPAM Bapak Fajar Koem, dalam wawancaranya mengatakan bahwa:

"Di kantor BLU-SPAM terdapat ruang tunggu sebagai salah satu bentuk pelayanan bagi pelanggan" (WW,FK,0202-2016)

Selenjutnya hasil wawancara dengan Kepala Desa, mengatakan bahwa:

Ada bangunan kantor BLU-SPAM yang menjadi lokasi atau tempat berkantor dan sebagai tempat untuk melakukan berbagai system palayanan penyediaan air bersih. Ada pula instalasi sebagai tempat pengelolaan air bersih yang berkualitas yang siap digunakan oleh masyarakat (WW,HTM,09-02-2016)

Wawancara tentang BLU-SPAM apakah ada loket pembayaran. Bendahara Unit BLU-SPAM Ibu Asti Taki, mengatakan bahwa :

"Dikantor BLU-SPAM sudah disediakan fasilitas berupa loket pembayaran tagihan rekening air" (WW,AT,11-02-2016)

Kepala Dusun Bapak Untuk Libunelo, dalam wawancaranya mengatakan bahwa:

"Di kantor BLU-SPAM ada tersedia ruangan yang berfungsi sebagai loket pembayaran tagihan rekening air" (WW,UL, 13-02-2016)

Hasil pengamatan yang didapatkan mengenai ruang tunggu dan loket pembayaran yang berada di kantor BLUSPAM, sesuai hasil wawancara dari semua narasumber itu benar adanya. Ada sebuah kantor yang berdiri dan memiliki ruangangan sebagai tempat untuk beraktifitas dan juga digunakan sebagai ruang tunggu bagi pelanggan, dan 
masyarakat umum, serta sebuah loket pembayaran tagihan rekening air.

Bedasarkan hasil penelitian dapatlah disimpulkan bahwa Ruang tunggu dan loket adalah dua hal yang tidak bisa dipisahkan dalam penyediaan layanan administrasi perkantoran, karena ruang tunggu dan loket merupakan sebuah tempat bagi konsumen/pelanggan yang datang datang untuk melakukan transaksi maupun kegiatan lainnya yang berhubungan dengan pelayanan.

\section{Dimensi Tanggapan (Responsiveness)}

Untuk menilai kualitas pelayanan oleh aparat dikantor BLU-SPAM perlu ada prosedur yang menunjukan apakah suatu pelayanan publik yang diberikan dapat dikatakan dapat dikatakan baik atau buruk. Berkualitas atau tudak umumnya yang sering muncul dimasyarakat adalah pelayanan itu sendiri yang merupakan ujung tombak yang berhadapan langsung dengan pelanggan. Itu sebabnya setiap petugas harus memiliki profesionalisme kerja mengenai cara memberikan pelayanan yang baik.

Hasil penelitian menunjukkan kemajuan para aparat BLU-SPAM untuk membantu keluhan pelanggan itu sudah baik, namun karena kurangnya personil yang ada di BLU-SPAM sehinggan pelayanan yang ada sering mengalami hambatan. Dalam hal kepedulian seluruh aparat sudah sangat baik dalam menanganani keluhan. Bahwa aparat dalam merespon keluhan masyarakat sudah sangat baik dan senantiasa lebih mengedepankan kepentingan konsumen dari pada yang lain. Hal ini dapat dibuktikan dengan sikap tanggap dari para aparat dalam menghadapi keluhan pelanggan.
Hasil wawancara dengan beberapa informan antara lain dengan Kasie Umum pada Kantor BLU-SPAM mengatakan bahwa:

"Setiap ada konsumen atau pelanggan yang datang dengan berbaga keluhan, oleh aparat akan direspon sebaik mungkin dan segera menjawab keluhan konsumen atau pelangga tersebut dengan tindakan". (WW,AT,17-02-2016)

Selanjutnya wawancara Kepala Desa Bulontio Barat mengatakan bahwa:

"Kemampuan para aparat sangat penting dalam memecahkan masalah terhadap setiap keluhan pelanggan. Kemampuan aparat yang dimaksdu yaitu tingkat kecakapan dan daya tanggap dalam merespon setiap keluhan seperti terjadinya kebocoran pipa, air tidak mengalir, serta masalah lainnya”. (WW,HT,17-02-2016)

Tokoh masyarakat dalam wawancaranya mengatakan bahwa:

"Aparat di BLU-SPAM sangat cepat dalam merespon terhadap apa yang menjadi keluhan pelanggan, sebaga contoh ketika terjadi penyumbatan air dirumahnya, dengan cepat petugas distribusi melakukan perbaikan terhadap masalah yang ada dirumahnya" (WW,NU,17-02-2016)

\section{Dimensi Jaminan (Assurance)}

Hasil penelitian menunjukkan bahwa para aparat dalam menjalankan tugas sudah sesuai dengan tupoksi masingmasing. Artinya bahwa setiap aparat sudah bisa mempertanggung jawabkan kinerja mereka terhadap atasan. Dalam menjaga rahasia dan kepercayaan pelanggan sudah tidak diragukan lagi, hal ini karena rahasia kualitas air benar-benar dijaga sebaik mungkin.

Pengetahuan dan tugas fungsi dari aparat sudah dilaksanakan dengan penuh 
tanggungjawab, dan seluruh aparat dalam menjaga rahasia dan kepercayaan pelanggan sudah sangat baik. Berdasarkan hal tersebut, kerjasama yang baik antara pihak BLU-SPAM dan Pelanggan perlu ditingkatkan dan dijaga dengan baik, karena hal tersebut sangat berpengaruh terhadap pelayanan dan penilaian.

Seperti hasil wawancara yang diungkapkan oleh Kepala BLU-SPAM Bapak Fajar Koem, mengatakan bahwa:

"Dari jumlah jaringan yang ada sejak dari tahun 2010 sampai dengan tahun 2016, pemasangan instalasi sudah mencapai 95\% dari target yang ditetapkan, yaitu 250 KK menjadi 850 KKditahun 2016, hal itu kemudian membuktikan kemampuan aparat BLU-SPAM dalam melaksanakan tugas pokok”. (WW,FK,22-02-2016)

Hasil wawancara dengan Kasie Keuangan diperoleh jawaban bahwa:

"Dari tagihan rekening yang ada setiap bulan, rata- rata pembayaran oleh pelanggan diatas target yang ditetapkan. Yang jika dilakukan evaluasi pertahun maka akumulasi pendapatan BLU-SPAM desa bulontio barat kecamatan sumalata selalu mendapatkan nilai yang tinggi”. (WW,AT,23-02-2016)

Kepala Desa Bulontio Barat Bapak hayun Taluhumala, mengatakan bahwa:

"Dari segi kualitas pengetahuan para aparat sudah memiliki keterampilan dan kualitas kinerja yang baik fungsi aparat sudah mereka jalankan dengan baik sesuai dengan tupoksi yang ada. Dari tahun ketahun progress kualitas aparat terus meningkat seiring dengan meningkatnya jumlah pelanggan". (WW,HT,24-02-2016)

\section{Dimensi Empati (Emphaty)}

Menurut hasil pengamatan bahwa proses pelayanan publik oleh aparat BLUSPAM sudah sangat transparansi dan berkualitas . misalnya layanan pengaduan dan keluhan juga tagihan rekening air baik melalui lisan maupun tulisan.

Para aparat BLU-SPAM didalam kepedulian dan perhatiannya kepada pelanggan, telah mememberikan berbagai kemudahan dalam pelayanan kepada pelanggan. Sebagai layanan public yang memberikan pelayanannya, aparat BLUSPAM selalu siap dalam membantu masyarakat yang membutuhkan pelayanan.

Wawancara tentang perhatian aparat terhadap konsumen/pelanggan dalam proses pelayanan.Kepala BLU-SPAM menjelaskan dalam wawancaranya bahwa: "Aparat BLU-SPAM sangat memperhatikan konsumen/pelanggan dalam proses pelayanan. Karena jika BLU-SPAM balai layanan dalam pelayanan public maka yang terpenting adalah bagaimana memberikan bantuan, perhatian dan kemudahan kepada masyarakat dalam rangka pelayanan. Hal ini kemudian mendorong sikap profesioanlisme dalam bekerja dari para aparat BLU-SPAM". (WW,FK,04-032016)

Tekhnisi BLU-SPAMMisran Lune, dalam wawancaranya mengatakan bahwa:

"Perhatian kami sebagai aparat BLUSPAM dalam menghadapi bermacammacam keluhan, adalah dengan menggunakan seluruh kemampuan dan kompetensi yang ada. Hal tersebut untuk memastikan bahwa keluhan pelanggan akan terjawab dengan baik". (WW,ML,0503-2016)

Kasie Keuangan Ibu Asti Taki, menjelaskan dalam wawancaranya bahwa:

"Salah satu bentuk perhatian kami terhadap pelanggan adalah dengan melakukan pengarsipan data - data pelanggan sebaik mungkin. Hal ini menjaga jangan sampai ada pelanggan 
yang kehilangan bukti tagihan rekening air maka data pembayarannya masih tersimpan dengan baik" (WW,AT,06-032016)

\section{Pembahasan}

Untuk Dimensi Reliability Berdasarkan hasil wawancara yang telah diuraikan diatas, bahwa aparat yang ada di BLU-SPAM dalam penanganan berbagai masalah sudah cukup baik walaupun belum maksimal. Selanjutnya untuk dimensi Tangibles Berdasarkan hasil pengamatan penulis pada dimensi bukti langsung (tangibles) masih terdapat banyak kekurangan fasilitas seperti kurangnya peralatan untuk pemasangan baru meter air, fasilitas yang berkaitan dengan penanggulangan pengaduan keluhan pelanggan dan terutama fasilitas pelayanan pembayaran rekening air dalam hal ini komputer. Penataan ruang tunggu yangbelum maksimal. Selain itu, belum tersedianya ruangan khusus operator dan adminitrasi pembayaran tagihan rekening air. Kekurangan lainnya yaitu belum adanya penataan atau pengadaan papan informasi yang dapat membantu masyarakat dalam pengurusan administrasi di Kantor BLU-SPAM. Dengan demikian dapat disimpulkan bahwa sarana dan prasarana di Kantor BLU-SPAM Desa Bulontio Barat masih banyak yang kurang sehingga dapat menyebabkan terhambatnya kualitas pelayanan publik di Desa Bulontio Barat dalam rangka pelayanan penyediaan air bersih.

Untuk dimensi responsiveness Berdasarkan hasil wawancara yang telah diuraikan diatas dan pengamatan penulis, kualitas pelayanan di Kantor BLU-SPAM Desa Bulontio Barat bila dilihat dari dimensi daya tangap sudah baik, dimana pemahaman atau sosialisasi tentang persyaratan layanan prosedur pemasangan baru meter air, pengaduan keluhan dan pembayaran tagihan. Keterbukaan layanan kepada masayarakat pelanggan BLUSPAM selalu dilakukan pada saat pendaftaran pemasangan baru meter air, pengaduan keluhan dan pembayaran tagihan. Hal ini membuktikan bahwa daya tanggap sangat berpengaruh dalam mewujudkan kualitas pelayanan publik. Ini dibuktikan dengan cepat tanggapnya aparat walaupun masih terdapat keluhan-keluhan pelanggan dalam pelaksanaan prosedur pelayanan kepada masyarakat pengguna air bersih BLU-SPAM Desa Bulontio Barat Kecamatan Sumalata kabupaten Gorontalo Utara. Selanjutnya dimensi assurance Hasil wawancara dan pengamatan peneliti dalam hal jaminan ini sudah baik meskipun masih ada kekurangan tentang pengetahuan aparat perihal pelayanan publik yang berkualitas. Meskipun demikian aparat telah melaksanakan pelayanan maksimal sehingga masyarakat merasa puas dengan pelayanan yang diterima. Dan dimensi terakhir mengenai empathy bahwa Perhatian secara terbuka akan menunjukan suatu kualitas pelayanan yang baik. Oleh karena itu, empati pegawai BLU-SPAM Desa Bulontio Barat sudah baik, namun Diharapkan untuk dapat lebih meningkatkan keramahan dan kualitas dalam melayani masyarakat dalam berbagai jenis pelayanan, sehingga bisa terjalin hubungan yang baik antara aparat pelaksana pelayanan publik dengan masyarakat yang melakukan pengurusan pelayanan penyediaan air bersih.

\section{PENUTUP}

\section{Simpulan}

Berdasarkan analisis data secara deskripsi di atas tentang kualitas pelayanan publik pada BLU-SPAM Desa Bulontio 
Barat Kecamatan Sumalata Kabupaten Gorontalo Utara, maka dapat dikemukakan beberapa kesimpulan bahwa;

\section{Dimensi Relaibility}

Untuk dimensi dapat dikatakan cukup baik. Hal ini didukung oleh para pegawai yang melayani pelanggan sesuai dengan prosedur yang telah ditetapkan. Pegawai yang bekerja tidak sesuai dengan SOP diberikan surat teguran secara lisan maupun tertulis.

\section{Dimensi Tangibles}

Dari dimensi ini kualitas pelayanan publik pada BLU-SPAM Desa Bulontio Barat Kecamatan Sumalata dari dimensi bukti langsung (tangibles) masih belum maksimal dikarenakan, fasilitas yang tersedia belum memadai karena belum memiliki kantor tapi yang ada hanya berupa loket yang dijadikan tempat untuk melakukan aktifitas berkantor, atau untuk menerima tagihan rekening air.

\section{Dimensi daya tanggap (responsiveness)}

Dapat dikatakan cukup baik namun perlu ditingkatkan lagi. Pada pemasangan baru jika calon pelanggan memenuhi prosedur dan persyaratan dengan lengkap diselesaikan sekitar 1-2 bulan. Pada pengaduan gangguan diselesaikan dalam 2x24 jam atau sekitar 2-3 hari. Pada pembayaran tagihan diselesaikan sekitar 510 menit.

4. Dimensi jaminan (assurance)

Dapat dikatakan cukup baik namun perlu ditingkatkan lagi. Hal ini didukung oleh adanya tanggung jawab para pegawai dengan membuat laporan harian, laporan bulanan, dan laporan tahunan. Dari dimensi empati (empathy) dapat dikatakan cukup baik.

5. Dimensi emphaty

Dapat dikatakan cukup baik, perhatian para aparat terhadap setiap keluhan pelanggan baik mengenai kualitas air yang ada itu dijelaskan dengan sejujur-jujrnya oleh aparat tanpa ada unsur yang dirahasiakan di dalam pelayanannya.

\section{Saran}

Berdasarkan hasil penelitian maka disarankan :

1. Adanya peran serta dari Pemerintah, baik pemerintah pusat maupun pemerintah provinsi dan Kaupaten/Kota dalam hal penambahan atau penyediaan sumber air baku di Desa Bulontio Barat sehingga dapat memenuhi kebutuhan air bersih bagi masyarakat Desa Bulontio Barat pada khususnya.

2. Penambahan dan perbaikan sarana dan prasarana serta infrastruktur BLUSPAM Desa Bulontio Barat dalam proses pendistribusian air bersih agar lebih ditingkatkan lagi sehingga distribusi air dapat menjangkau rumahrumah penduduk di dataran tinggi.

3. Adanya peran serta dari Pemerintah dalam hal penyediaan listrik yang memadai dalam menunjang kegiatan distribusi air bersih oleh BLU-SPAM Desa Bulontio Barat sehingga distribusi air dapat berjalan dengan lancar.

4. Meningkatkan kualitas air bersih oleh BLU-SPAM Desa Bulontio Barat salah satunya dengan perawatan/pembersihan pipa-pipa secara rutin.

5. Mengadakan sosialisasi/himbauan kepada pelanggan baik secara tertulis maupun penyampaian secara lisan agar pelanggan dapat menjaga meteran air dan jaringan pipa rumah, hemat dalam pemakaian air, melaporkan setiap terjadi gangguan di lapangan, maupun membayar tagihan bulanan dengan tepat waktu.

\section{DAFTAR PUSTAKA}


Arikunto Suharsimi.2010. Prosedur Penelitian Suatu Pendekatan. Jakarta : Rineka Cipta

Creswell, John W.2010. Research Design, Pendekatan Kualitatif, Kuantitatif dan Mixed, Edisi Ketiga, Cetakan Pertama. Yogyakarta : Pustaka Pelajar

Kotler, Philip, dan Kevin Lanne K. 2000. Manajemen Pemasaran. Jakarta : PT.Indeks

Moenir, H.A.S. 2001. Manajemen Pelayanan Umum di Indonesia. Jakarta : Bumi Aksara

Maleong, Lexy J.2007. Metodologi Penelitian Kualitatif. Bandung : PT. Remadja Resdakarya

Sampara, Lukman.2000. Manajemen Kualitas Pelayanan. Jakarta: STIA LAN Pres

Sinambela,LP. 2013. Reformasi Pelayanan Publik; Teori, Kebijakan \& Implementasi. Jakarta: PT Bumi Aksara

Sugiyono.2012. Metode Penelitian Administrasi. Bandung : Alfabeta

The Liang Gie. 2008. Administrasi Kantor Modern. Yogyakarta: Nur Cahya Warella.2009. Administrasi Negara dan Kualitas Pelayanan Publik. Semarang : Jurnal Undiv

Wirjanti, Endang. 2006. Akuntabilitas dan Pengukuran Kinerja Pemerintah. Jurnal Akuntansi dan Keuangan 